\title{
New thiopyridine complexes: design, electrochemical preparation and bio- logical assessment
}

\author{
Osama I. El-Sabbagh ${ }^{1 *}$, Yamany B. Yamany ${ }^{1}$, Hany A. Eldeab ${ }^{1}$ \\ ${ }^{1}$ Department of Pharmaceutical Chemistry, College of Pharmacy, Taif University, P.O. Box: 888 Al-Haweiah, Zip Code \\ 21974, Taif, Saudi Arabia. \\ "Corresponding author: e-mail: osamaelsabbagh@yahoo.com
}

\begin{abstract}
Novel complexes of $\mathrm{Ru}$ (III), $\mathrm{Cu}$ (II) and $\mathrm{Au}$ (III) (2-4) were prepared using 6-phenyl-2-thioxo-4-(trifluoromethyl)-1,2dihydropyridine-3-carbonitrile (HL,1) adopting either electrochemical or traditional chemical methods. The electrochemical method is preferred in the synthesis of the complexes than the chemical one because it affords pure products with higher yields in shorter reaction time. The novel thiopyridine complexes were characterized by elemental analyses, IR, ${ }^{1} \mathrm{H},{ }^{19} \mathrm{~F}-\mathrm{NMR}$, TGA and DTA measurements. The antimicrobial activity evaluation revealed that the complex bearing copper metal $\mathbf{3}$ has nearly the same activity as the reference drug ciprofloxacin. Anti-inflammatory activity evaluation showed that complex $\mathbf{4}$ containing gold displayed anti-inflammatory activity higher than the reference drug celecoxib upon using carrageenan rat hind paw edema method.
\end{abstract}

Keywords: Thiopyridine, complexes, electrochemical, antimicrobial, anti-inflammatory.

\section{INTRODUCTION}

The emergence of bacterial resistance to existing antibiotics is a worldwide issue. Morbidity and mortality due to enteric bacterial infections caused important healthy problems worldwide mainly in developing countries ${ }^{1}$. New classes of antimicrobial compounds are therefore urgently needed to control the virulence of the multidrug resistant pathogens. Electrochemistry is defined as the branch of chemistry that examines the phenomena resulting from combined chemical and electrical effects ${ }^{2}$. Studies reported that some sulphur containing ligands showed anticarcinogenic, antibacterial, tuberculostatic, and antifungal activities. Moreover, 2-mercapto pyridine carboxylic acids are versatile ligands that containing exocyclic sulphur and endocyclic nitrogen atoms which act as a bidentate ligand through the pyridine $\mathrm{N}$ of the heterocycle and thiolate $\mathrm{S}$ atoms coordinated to metal ion $^{3,4}$. Other study found that 3 -substituted thiopyridines exhibited antibacterial, antimalarials and anticancer activities ${ }^{5}$.

Ruthenium is widely studied due to its versatility and potential applications in several fields of the science ${ }^{6,7}$. It was reported that three complexes containing ruthenium exhibited in vitro antitumor activity which is better than cisplatin at the same concentration. These complexes showed also antimicrobial activity against $M$. tuberculosis ${ }^{8}$. A study reported that some metal complexes containing copper were found to be possess potentially antibacterial against $S$. aureus and B. subtitles ${ }^{9}$. Gold compounds have been used since ancient times, particularly in traditional Chinese, Egyptian and Indian medicines, where they were found to be effective in treating inflammation, infection and tuberculosis ${ }^{\mathbf{1 0}, 11}$. Others reported that gold compounds not only limited to inflammatory diseases but also were beneficial as anticancer ${ }^{12}$. Jumaa et al found that gold nanoparticles possess antibacterial activity against Gram-positive (Staphylococcus aureus) and negative bacteria (Pseudomonas aeroginosa) using agar well diffusion method ${ }^{13}$.

In this work, we aim to synthesize some metal complexes of $\mathrm{Ru}$ (III), $\mathrm{Cu}$ (II) and $\mathrm{Au}(\mathrm{III})$ utilizing the ligand 6-phenyl-2-thioxo-4-(trifluoromethyl)-1,2dihydropyridine-3-carbonitrile by electrochemical and traditional chemical methods hoping to possess superior antimicrobial and anti-inflammatory activities.

\section{EXPERIMENTAL PART}

\section{Chemistry \\ General:}

Infrared spectra were recorded with a Thermo Nicolet Nexus 470 FT-IR spectrometer in the range 4000-400 ( $v$, $\mathrm{cm}^{-1}$ ) on samples in potassium bromide disks. ${ }^{1} \mathrm{H}-\mathrm{NMR}$ spectra, was obtained on Varian Gemini $400 \mathrm{MHz}$ FT NMR spectrometer in DMSO- $d_{6}$; chemical shifts were recorded in $\delta(\mathrm{ppm})$ units, relative to $\mathrm{Me}_{4} \mathrm{Si}$ as an internal standard. Shimadzu LCMS-QP 800 LC-MS and AB-4000 Q-trap LC-MS/MS utilized to determine the mass spectra. Elemental analysis data were obtained using a 2400 II series CHN Analyzer (Perkin Elmer, Waltham, MA, USA). The reagents were purchased from Aldrich Chemical Co. and used without further purification.

Method A: Electrochemical synthesis of complexes

The electrochemical technique was performed according to the previously reported procedure ${ }^{14,15}$. A cell unit consisted of a $100 \mathrm{~mL}$ beaker containing anhydrous acetone solution of the thiopyridine derivative, $\mathbf{1}$ with a platinum cathode and a sacrificial anode $(\mathrm{Cu}$ or $\mathrm{Au}$ or $\mathrm{Ru}$ ) immersed in the liquid phase. Electrolysis of copper or gold into $60 \mathrm{~mL}$ of anhydrous acetone solution of the organic ligand (1) $(0.49 \mathrm{~g}, 2 \mathrm{mmol}), 2.5 \mathrm{mg} \mathrm{Et}{ }_{4} \mathrm{NClO}_{4}$ dissolved in two drops of water and $40 \mathrm{~mA}$ current led to dissolution of $34 \mathrm{mg}$ of metal electrode during 30 $\min .\left(E_{\mathrm{f}}=0.5 \mathrm{~mol} . \mathrm{F}^{-1}\right)$. Since, most of the products are insoluble in the reaction mixture, the collection procedure involved filtration, after which the solid was washed with diethyl ether.

Method B, Traditional chemical synthesis:

A mixture of metal $(\mathrm{Ru}, \mathrm{Cu}$ or $\mathrm{Au})$ chloride $(0.16$ $\mathrm{mmol}$ ) and 6-phenyl-2-thioxo-4-(trifluoromethyl)-1,2dihydropyridine-3-carbonitrile (HL,1, $0.16 \mathrm{mmol}$ ) in 40 $\mathrm{ml}$ acetone was degassed and then heated to reflux for 
10-12 h. The reaction mixtures were cooled, and the solvent was removed under vacuum. The residue was washed by hot benzene followed by petroleum ether. The complexes were left to dry under vacuum.

6-phenyl-2-thioxo-4-(trifluoromethyl)-1,2-dihydropyridine-3-carbonitrile (1). Yellowish brown, $\mathrm{mp}=$ $256{ }^{\circ} \mathrm{C}^{16} \mathrm{IR}\left(\mathrm{KBr}, \mathrm{cm}^{-1}\right) 3493(\mathrm{NH}), 2226(\mathrm{CN}) ;{ }^{1} \mathrm{H}-$ -NMR (400 MHz, DMSO- $\left.d_{6}\right) \delta=7.22$ (s, pyridine H-5), 7.63-7.97 (m, Ar-H) ppm; ${ }^{19} \mathrm{~F}-\mathrm{NMR}$ (376 MHz, DMSO $\left.-d_{6}\right) \delta=(-62.47)\left(\mathrm{s}, \mathrm{F}, \mathrm{CF}_{3}\right) \mathrm{ppm}$. Anal. Calcd for $\mathrm{C}_{13} \mathrm{H}_{7} \mathrm{~F}_{3} \mathrm{~N}_{2} \mathrm{~S}$ : C, 55.71; H, 2.52; N, 10.00. Found: C, 55.74; H, 2.50; N, 10.03 .

Tris((3-cyano-6-phenyl-4-(trifluoromethyl)pyridin-2-yl) thio)ruthenium (2). Dark brown, yield: method A, $89 \%$ (method B: 61\%), $\mathrm{mp}>300^{\circ} \mathrm{C}$; IR $\left(\mathrm{KBr}, \mathrm{cm}^{-1}\right) 2226$ (CN); ${ }^{1} \mathrm{H}-\mathrm{NMR}\left(400 \mathrm{MHz}, \mathrm{DMSO}-d_{6}\right) \delta 7.22$ (s, pyridine $\mathrm{H}-5), 7.61-7.89$ (m, Ar-H) ppm; ${ }^{19} \mathrm{~F}-\mathrm{NMR}$ (376 $\left.\mathrm{MHz}, \mathrm{DMSO}-d_{6}\right) \delta=(-62.48)\left(\mathrm{s}, \mathrm{F}, \mathrm{CF}_{3}\right) \mathrm{ppm} ; \mathrm{LC}-\mathrm{MS}$ (ionization method): m/z $939(\mathrm{M}+1)$; Anal. Calcd for $\mathrm{C}_{39} \mathrm{H}_{18} \mathrm{~F}_{9} \mathrm{~N}_{6} \mathrm{RuS}_{3}$ : C, 49.89; H, 1.93; N, 8.95. Found: C, 49.91; H, 1.95; N, 8.98.

Bis-((3-cyano-6-phenyl-4-(trifluoromethyl)pyridin-2-yl) thio)copper diacetone (3). Previously prepared by classical method ${ }^{17}$. Brown, yield: method A, 96\% (method $\mathrm{B}: 74 \%), \mathrm{mp}>300^{\circ} \mathrm{C}$; IR $\left(\mathrm{KBr}, \mathrm{cm}^{-1}\right) 2226(\mathrm{CN})$; ${ }^{1} \mathrm{H}-\mathrm{NMR}\left(400 \mathrm{MHz}, \mathrm{DMSO}-d_{6}\right) \delta=7.24$ (s, pyridine $\mathrm{H}-5)$, 7.59-8.04 (m, H, Ar-H) ppm; ${ }^{19} \mathrm{~F}-\mathrm{NMR}$ (376 $\left.\mathrm{MHz}, \mathrm{DMSO}-\mathrm{d}_{6}\right) \delta=(-62.51)\left(\mathrm{s}, \mathrm{F}, \mathrm{CF}_{3}\right) \mathrm{ppm} ; \mathrm{LC}-\mathrm{MS}$ (ionization method): $\mathrm{m} / \mathrm{z} 739(\mathrm{M}+1)$; Anal. Calcd for $\mathrm{C}_{32} \mathrm{H}_{24} \mathrm{CuF}_{6} \mathrm{~N}_{4} \mathrm{O}_{2} \mathrm{~S}_{2}$ : C, 52.06; H, 3.28; N, 7.59. Found: C, 52.09; H, 3.21; N, 7.61.

Tris-((3-cyano-6-phenyl-4-(trifluoromethyl)pyridin-2-yl)thio)gold (4). Light brown, yield: method A, 91\% $($ method B: $64 \%), \mathrm{mp}>300^{\circ} \mathrm{C}$; IR $\left(\mathrm{KBr}, \mathrm{cm}^{-1} 2226\right.$ $(\mathrm{CN}) ;{ }^{1} \mathrm{H}-\mathrm{NMR}\left(400 \mathrm{MHz}, \mathrm{DMSO}-d_{6}\right) \delta=7.27$ (s, H, pyridine $\mathrm{H}-5), 7.53-7.98$ (m, H, Ar-H) ppm, ${ }^{19} \mathrm{~F}-\mathrm{NMR}$ $\left(376 \mathrm{MHz}, \mathrm{DMSO}-\mathrm{d}_{6}\right) \delta=(-62.48)\left(\mathrm{s}, 3 \mathrm{~F}, \mathrm{CF}_{3}\right) \mathrm{ppm}$; LC-MS (ionization method): $\mathrm{m} / \mathrm{z} 1035(\mathrm{M}+1)$; Anal. Calcd for $\mathrm{C}_{39} \mathrm{H}_{18} \mathrm{AuF}_{9} \mathrm{~N}_{6} \mathrm{~S}_{3}: \mathrm{C}, 45.27 ; \mathrm{H}, 1.75 ; \mathrm{N}, 8.12$. Found: C, 45.28; H, 1.77; N, 8.14.

\section{Biological activity evaluation}

\section{Antimicrobial activity}

\section{Methodology:}

The ligand (1) and complexes (2-4) which were previously prepared by method A, were dissolved in $D M F$ at concentration $10 \mathrm{mg} / \mathrm{mL}$. The antibacterial ciprofloxacin and the antifungal nystatin were used as references drugs at the same dose level while DMF was used as a negative control ${ }^{18}$. Nutrient agar (Oxoid, England) was inoculated with one bacterial strain. Bacterial strains used were Gram-positive bacteria (Staphylococcus aureus and Bacillus subtilis) and Gram-negative bacteria (Esherichia coli). Saburaud's dextrose agar (Oxoid, England) was seeded with Candida albicans as representative of fungi. After solidification, cups were made by cork borer, and then filled with $50 \mu \mathrm{l}$ from compounds solution. Each compound was assessed in triplicate. The plates were incubated overnight at $37^{\circ} \mathrm{C}$ and then the inhibition zones were measured in $\mathrm{mm}$. The results of antimicrobial activity for the new compounds were recorded in Table 2. Bacterial and fungal strains were isolated and identified by Department of Microbiology, Faculty of Pharmacy, Zagazig University, Zagazig Egypt.

\section{Statistical analysis.}

Data were analyzed using computer program SPSS. The differences in mean values were determined by analysis of variance (one-way ANOVA) followed by Least Significant Difference (LSD).

\section{Anti-inflammatory activity evaluation}

\section{Materials}

Carrageenan (carrageenan kappa-type III) and all other reagents were purchased from Sigma Chemical Co. (St. Louis, MO, USA). The ligand (1), the test compounds (2-4) prepared by method A and reference drug celecoxib were used in the following assays. Housing and management of the animals and the experimental protocols were made as stipulated in the Guide for Care and Use of Laboratory Animals Guidelines of the National Institutes of Health (NIH), and accepted by the local authorities of Zagazig University, Zagazig, Egypt.

\section{Animals}

Mature male albino rats weighing 150-200 g were used. All experimental animals were provided from the Faculty of Veterinary Medicine, Zagazig University, Egypt. All animals were held under standard laboratory conditions in the animal house (temperature $27^{\circ} \mathrm{C}$ ) with a 12/12 light-dark cycle. Animals were fed laboratory diet and water ad libitum. The animal experiments were performed in accordance with international guidelines.

\section{Method:}

The rat hind paw edema method ${ }^{\mathbf{1 9}}$ by Winter et al., 1962 was applied to determine the anti-inflammatory activity of the ligand (1) and the test complexes (2-4) using celecoxib as a standard. The animals were divided into 6 equal groups (each of six). The first group was left as a control group while the second group was injected i.p. with celecoxib at a dose of $18 \mathrm{mg} / \mathrm{Kg}$ body weight. The ligand and the test compounds were injected i.p. in the remaining groups at the same dose level. After $1 \mathrm{~h}$, edema in the right hind paw was induced by injecting 0.1 $\mathrm{mL}$ of $10 \%$ carrageenin. The thickness of the paw was measured using a skin caliber $1,2,3$, and $4 \mathrm{~h}$ after the carrageenin injection to determine the anti-inflammatory activity of the test compounds (Table 3).

\section{RESULTS AND DISCUSSION}

\section{Chemistry}

In the present work, the targets metal complexes of $\mathrm{Ru}$ (III) , Cu (II) and $\mathrm{Au}(\mathrm{III})(\mathbf{2 - 4})$ were prepared starting from the ligand the 6-phenyl-2-thioxo-4-(trifluoromethyl)1,2-dihydropyridine-3-carbonitrile (1). The latter was prepared adopting the reported procedure ${ }^{\mathbf{1 6}}$. This ligand (HL,1) exists in the following tautomeric forms (Fig. 1).

The targets metal complexes of $\mathrm{Ru}$ (III) $\mathrm{Cu}$ (II) and $\mathrm{Au}$ (III) (2-4) were prepared adopting two methods. The first, electrochemical method depends on direct oxidation of the metals in the presence of a ligand solution. It is a one-step process which represents a convenient 
<smiles>N#Cc1c(C(F)(F)F)cc(-c2ccccc2)nc1S</smiles>

Figure 1. Tautomeric forms of ligand (HL,1)

and simple route to a variety of transition metal complexes. Measurements of the electrochemical efficiency, Ef, defined as moles of metal dissolved per Faraday of electricity, for the $\mathrm{M} / \mathrm{L}$ system (where $\mathrm{M}=\mathrm{Ru}, \mathrm{Cu}$, and $\mathrm{Au}$ and $\mathrm{L}=$ ligand used) gave $\mathrm{Ef}=0.5 \pm 0.05 \mathrm{~mol}$ $\mathrm{F}^{-1}$. The second, traditional chemical method, depends on reaction of equimolar amounts of metal $(\mathrm{Ru}, \mathrm{Cu}$ or $\mathrm{Au}$ ) chloride with the thiopyridine derivative (HL,1) in acetone by heating the reactants at reflux for $10-12 \mathrm{~h}$. It was noted that the first, electrochemical method is preferred in the synthesis of the complexes than the second chemical method because it affords pure products with higher yields in shorter reaction time.<smiles>[R10][Y4]#[Y10][H]</smiles>

$$
\text { 2: } \mathrm{M}=\mathrm{Ru} \quad \text { 4: } \mathrm{M}=\mathrm{Au}
$$

The isolated thiopyridine complexes (Fig. 2) were characterized by their elemental analyses, TGA, DTA measurements and different spectroscopic methods. The results of the elemental analyses are in good agreement with the calculated values.

IR for thiopyridine ligand (1) revealed the appearance of strong absorption band at $v=3493 \mathrm{~cm}^{-1}$ due to $\mathrm{NH}$ group as well as another band at $v=2226 \mathrm{~cm}^{-1}$ due to $\mathrm{CN}$ group. Moreover, IR for thiopyridine complexes showed the disappearance of $\mathrm{NH}$ band at $v=3493 \mathrm{~cm}^{-1}$ in addition to a decrease in the intensity of the absorption band due to $\mathrm{CN}$ group at $2226 \mathrm{~cm}^{-1}$ confirming the formation of metal complexes 2-4 (Fig. 3).

Furthermore, thermoanalytical methods, such as thermogravimetry (TG), are excellent tools to follow the thermal decomposition of the complexes. The thermogravimetric analysis results of thiopyridine (HL, 1) and its metal complexes proved the formation of metal complexes as indicated in table (1). The thermal behavior of the Au (III) complex as an example of pyridinethione metal complexes was studied by thermogravimetric (TG) and differential thermal analysis (DTA) as indicated in figure 4 .<smiles>CC(C)(C)c1cc(-c2ccccc2)nc2sn(C(C)(C)C)c3c(C(C)(C)C)cc(-c4ccccc4)nc3[nH]c12</smiles>

Figure 2. Suggested structures of the complexes (2-4)

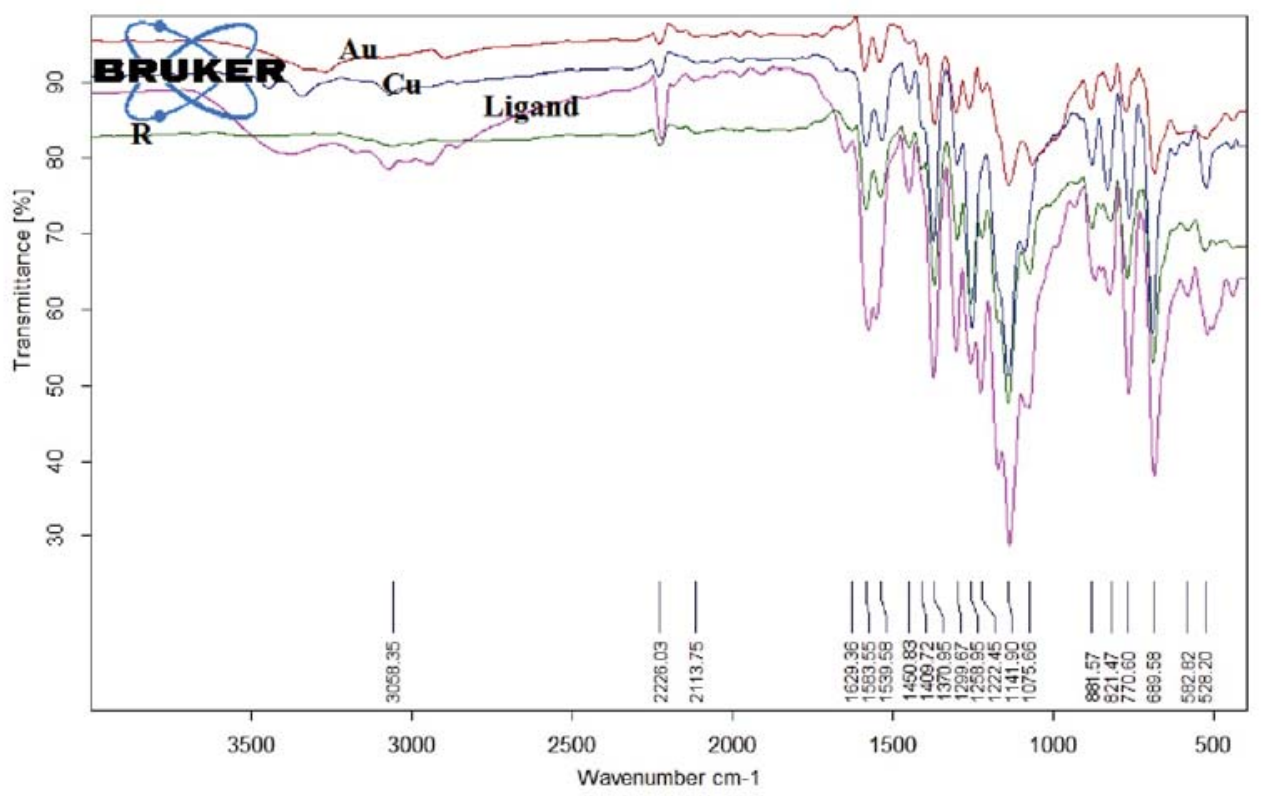

Figure 3. IR spectrum for ligand (1) and metal complexes (2-4); Ligand: compound 1, Au: complex 4, Cu: complex 3, R: complex 2 
Table 1. The thermal data of 6-phenyl-2-thioxo-4-(trifluoromethyl)-1,2-dihydropyridine-3-carbonitrile ligand (1) and its metal complexes (2-4)

\begin{tabular}{|c|c|c|c|c|c|c|}
\hline \multirow{2}{*}{ Compound } & \multirow{2}{*}{ steps } & \multirow{2}{*}{$\begin{array}{c}\text { Temperature } \\
\text { ring }\left[{ }^{\circ} \mathrm{C}\right]\end{array}$} & \multicolumn{2}{|c|}{ TG weight loss [\%] } & \multirow{2}{*}{ Assignments } & \multirow{2}{*}{$\mathrm{T}_{\max } /{ }^{\circ} \mathrm{C}$} \\
\hline & & & Calc. & Found & & \\
\hline \multirow{2}{*}{ HL (1) } & 1 & $25-380$ & 72.60 & 73.10 & $3 / 2 \mathrm{~F}_{2}, \mathrm{~N}_{2}, \mathrm{H}_{2} \mathrm{CS}$ and $3 \mathrm{C}_{2}$ fragments & 337 \\
\hline & 2 & More than 380 & 27.40 & 26.90 & $\left(\mathrm{C}_{6} \mathrm{H}_{5}\right)$ & 573 \\
\hline \multirow{4}{*}{$R u(L)_{3} \quad(2)$} & 1 & $25-344$ & 22.05 & 21.84 & $3 / 2\left(\mathrm{C}_{2} \mathrm{~F}_{6}\right)$ fragments & 243 \\
\hline & 2 & $344-440$ & 16.62 & 16.35 & $3(\mathrm{NCCN})$ fragments & 332 \\
\hline & 3 & $440-1000$ & 42.81 & 43.22 & 3/2(HCCH), 3/2(SCCS) and three phenyl rings fragments. & 449 \\
\hline & 4 & More than 1000 & 18.44 & 18.90 & $3 \mathrm{C}_{2}$ and $\mathrm{Ru}$ metal residual & \\
\hline \multirow{3}{*}{$\mathrm{Cu}(\mathrm{L})_{2}(3)$} & 1 & $25-425$ & 51.90 & 51.98 & Two acetone, 2($\left(\mathrm{CF}_{3}\right), 2(\mathrm{NC}-\mathrm{CN})$ and $\mathrm{HCCH}$ molecules & 394 \\
\hline & 2 & $425-526$ & 18.40 & 18.96 & SCCS and $2 \mathrm{C}_{2}$ fragments & 501 \\
\hline & 3 & $526-$ more than 100 & 29.50 & 29.00 & phenyl ring and $\mathrm{Cu}(\mathrm{II})$ & 622 \\
\hline \multirow{3}{*}{$\mathrm{Au}(\mathrm{L})_{3}(4)$} & 1 & 25-316 & 35.07 & 35.16 & $2 / 3\left(\mathrm{C}_{2} \mathrm{~F}_{6}\right)$ and $3(\mathrm{NCCN})$ & 240 \\
\hline & 2 & $316-405$ & 38.34 & 37.80 & $3 / 2(\mathrm{HCCH}), 3 / 2(\mathrm{SCCS})$ and three phenyl rings fragment & 340 \\
\hline & 3 & 405 - more than 1000 & 26.59 & 27.04 & Residue metal of Au and $3 \mathrm{C}_{2}$ fragment & 482 \\
\hline
\end{tabular}

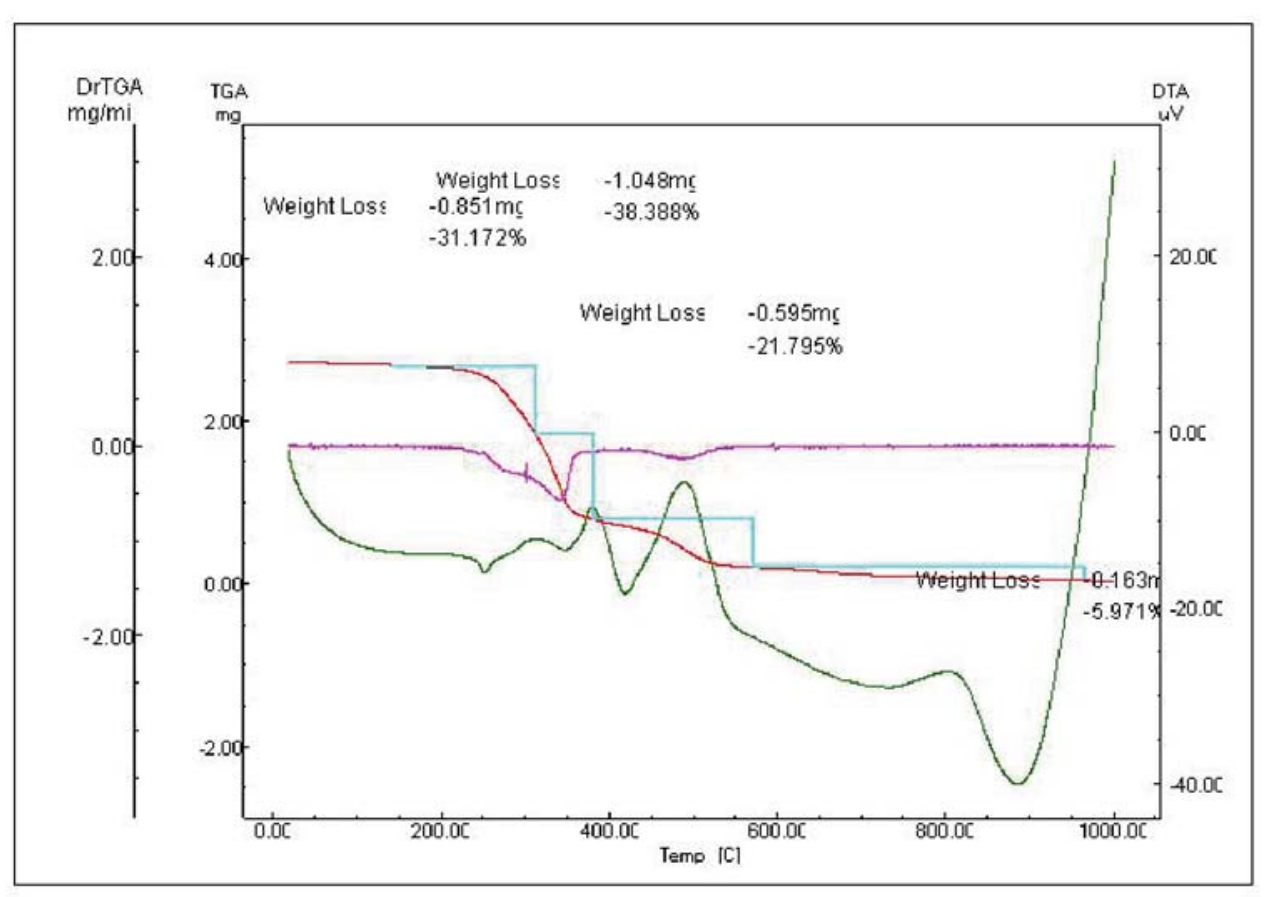

Figure 4. TGA and DTA thermogram for $\mathrm{Au}(\mathrm{L}) 3$

\section{Biological Activities}

The ligand (1) and the novel derivatives (2-4) were subjected to evaluate their in vitro antimicrobial as well as in vivo anti-inflammatory activities.

\section{Antimicrobial activity evaluation.}

The preliminary antimicrobial activity for the ligand and its metal complexes (1-4) was carried out using cup-plate technique. ${ }^{18}$ Among the metal complex derivatives (2-4), it was found that complex bearing copper metal $\mathbf{3}$ has nearly the same activity as the reference drug ciprofloxacin against both Gram-positive and negative bacteria. Other complexes $(\mathbf{2}, \mathbf{4})$ showed very weak antibacterial activity in comparison with the reference drug ciprofloxacin, so, copper metal is preferred than $\mathrm{Ru}$ and $\mathrm{Au}$ in inducing antibacterial. All the tested compounds did not show any antifungal activity (Table 2).

Anti-inflammatory activity evaluation:

Anti-inflammatory activity was evaluated by employing carrageenan rat hind paw edema method using celecoxib as a reference drug ${ }^{19}$. Mean changes in paw edema thickness after 1, 2, 3 and $4 \mathrm{~h}$ from induction of inflammation and edema inhibition given by the tested compounds and celecoxib at $18 \mathrm{mg} / \mathrm{kg}$ body weight dose level were displayed in Table 3. It was noted that complex 4 bearing gold displayed higher anti-inflammatory activity after $4 \mathrm{~h}$ than the reference drug celecoxib.

\section{CONCLUSIONS}

New complexes of $\mathrm{Ru}$ (III), Cu (II) and $\mathrm{Au}$ (III) (2-4) were prepared starting from pyridinethione ligand (HL,1) adopting electrochemical and traditional chemical procedures. The electrochemical method is preferred than the latter one because it affords pure products with higher yields in shorter reaction time. The preliminary antimicrobial activity evaluation revealed that complex bearing copper metal $\mathbf{3}$ has nearly the same activity as the reference drug ciprofloxacin. Anti-inflammatory ac- 
Table 2. Antimicrobial activity evaluation for compounds 1-4 expressed by diameter of inhibition zone (mm)\#

\begin{tabular}{|c|c|c|c|c|}
\hline \multirow{2}{*}{ Compound } & \multicolumn{3}{|c|}{ Diameter of inhibition zone [mm] } \\
\cline { 2 - 5 } & \multicolumn{2}{|c|}{ Gram- positive } & Gram- negative & Fungi \\
\cline { 2 - 5 } & Staphylococcus aureus & Bacillus subtilis & Escherichia. coli & $\begin{array}{c}\text { Candida } \\
\text { albicans }\end{array}$ \\
\hline & $6 \pm 0.2^{*}$ & $7 \pm 0.01^{*}$ & $5 \pm 0.3^{*}$ & - \\
\hline $\mathbf{1}$ & $9 \pm 0.4^{*}$ & $8 \pm 0.4^{*}$ & $7 \pm 0.2^{*}$ & - \\
\hline $\mathbf{3}$ & $16 \pm 0.3$ & $18 \pm 0.3$ & $12 \pm 0.5$ & - \\
\hline $\mathbf{4}$ & $6 \pm 0.2^{*}$ & $8 \pm 0.2^{*}$ & $4 \pm 0.4^{*}$ & - \\
\hline Ciprofloxacin & $17 \pm 0.8$ & $19 \pm 0.5$ & $12 \pm 0.3$ & $20 \pm 0.5$ \\
\hline Nystatin & - & - & - & \\
\hline
\end{tabular}

"Values were expressed as means \pm SD., ${ }^{*} P<0.001$ v.s ciprofloxacin.

Table 3. Anti-inflammatory activity of the tested compounds (1-4) and celecoxib (18 mg/kg p.o.) against carrageenan-induced hind paw edema in rats. (Mean \pm S.D; $\mathrm{n}=6$ )

\begin{tabular}{|c|c|c|c|c|c|}
\hline \multirow{2}{*}{ Compound } & \multirow{2}{*}{ Initial thickness (Zero time) } & \multicolumn{4}{|c|}{ Thickness of rat paw $(\mathrm{mm})$ after } \\
\hline & & 1 hour & 2 hours & 3 hours & 4 hours \\
\hline Control & $0.22 \pm 0.025$ & $0.77 \pm 0.02^{a}$ & $0.88 \pm 0.03^{a}$ & $0.88 \pm 0.03^{a}$ & $0.88 \pm 0.03^{a}$ \\
\hline Celecoxib & $0.22 \pm 0.025$ & $0.45 \pm 0.06^{\mathrm{d}}$ & $0.42 \pm 0.04^{d}$ & $0.45 \pm 0.04^{\mathrm{c}}$ & $0.50 \pm 0.05^{\mathrm{cd}}$ \\
\hline 2 & $0.22 \pm 0.025$ & $0.70 \pm 0.07^{\mathrm{ab}}$ & $0.67 \pm 0.04^{b}$ & $0.60 \pm 0.08^{b}$ & $0.55 \pm 0.06^{\mathrm{bcd}}$ \\
\hline 3 & $0.22 \pm 0.025$ & $0.50 \pm 0.04^{\mathrm{cd}}$ & $0.50 \pm 0.04^{\mathrm{cd}}$ & $0.52 \pm 0.04^{b}$ & $0.67 \pm 0.04^{b}$ \\
\hline 4 & $0.22 \pm 0.025$ & $0.55 \pm 0.08^{\mathrm{bcd}}$ & $0.50 \pm 0.06^{\mathrm{cd}}$ & $0.47 \pm 0.03^{c}$ & $0.45 \pm 0.04^{d}$ \\
\hline
\end{tabular}

"Means within the same column having different letters were significantly different at $P \leq 0.05$, one-way ANOVA

tivity evaluation showed that complex 4 containing gold displayed higher activity than the reference drug celecoxib upon using carrageenan rat hind paw edema method.

\section{ACKNOWLEDGMENTS}

This study was funded by the Deanship of Scientific Research, Taif University, KSA [research project number 5955-438-1].

The authors would like to thank Dr. Moamen Mahmoud Ez-Alarab at the Microbiology Department, Faculty of Pharmacy, at Zagazig University and Dr. Sameh M. El-Nabtity at Department of Pharmacology, Faculty of Veterinary Medicine Zagazig University for performing both the antimicrobial and anti-inflammatory activities.

\section{CONFLICT OF INTEREST}

The authors have declared that there is no conflict of interest.

\section{LITERATURE CITED}

1. Qadri, F., Svennerholm, A.M., Faruque, A.S.G. \& Sack, R.B. (2005). Enterotoxigenic Escherichia coli in developing countries: epidemiology, microbiology, clinical features, treatment, and prevention. Clin Microbiol Rev 18, 465-483.

2. Dreyse, P.A., Isaacs, M.A., Iturriaga, P.E. , Villagra, D.A., Aguirre, M.J., Kubiak, C.P., Glover, S.D. \& Goeltz, J.C. (2010). Electrochemical preparation of conductive films of tetrapyridylporphyrins coordinated to four $[\mathrm{Ru}(5-\mathrm{NO} 2-\text { phen }) 2 \mathrm{Cl}]^{+}$groups. J. Electroanal. Chem. 648 98-104.

3. Nevase, M.C., Pawar, R.D., Munjal, P.S., Dongare, A.E. \& Satkar, R.S. (2018). review on various molecule activity, biological activity and chemical activity of pyridine. Europ. J. Pharmac. Med. Res., 5(11), 184-192.

4. Jai, D., Nisha, B. \& Suman, K. (2011). Synthesis and characterization of novel Organosilicon (IV) complexes with pyridine dicarboxylic acid and Mercapto pyridine carboxylic acid; Int. J. Res. Chem. Environ. 1, 50-56.
5. Prachayasittikul, S., Treeratanapiboon, L., Ruchirawat, S. \& Prachayasittikul, V. (2009). novel activities of 1-adamantylthiopyridines as antibacterials, antimalarials and anticancers. EXCLI Journal, 8, 121-129.

6. Rodrigues, M.V.N., Corrêa, R.S., Vanzolini, K.L., Santos, D.S., Batista, A.A. \& Cass, Q.B. (2015). Characterization and screening of tight binding inhibitors of xanthine oxidase: an on-flow assay. RSC Adv.,5, 37533-37538.

7. Schmid, W.F., Zorbas-Seifried, S., John, R.O., Arion, V.B., Jakupec, M.A., Roller, A., Galanski, M., Chiorescu, I., Zorbas, H. \& Keppler, B.K. (2007). The first ruthenium-based paullones: syntheses, X-ray diffraction structures, and spectroscopic and antiproliferative properties in vitro. Inorg. Chem., 46, 3645-3656.

8. Lima, B.A.V., Corrêa, R.S., Graminha, A.E. , Kuznetsov, A., Ellena, J., Pavan, F.R., Leite, C.Q.F. \& Batista, A.A. (2016). "Anti-Mycobacterium tuberculosis and Cytotoxicity Activities of Ruthenium(II)/ Bipyridine/Diphosphine/Pyrimidine-2-thiolate Complexes: The Role of the Non- Coordinated N-Atom" $J$. Braz. Chem. Soc., 27(1), 30-40,; http://dx.doi.org/10.5935/01035053.20150237.

9. Kulkarni, A.D., Patil, S.A. \& Badami, P.S. (2009). Electrochemical Properties of some Transition Metal Complexes: Synthesis, Characterization and In-vitro antimicrobial studies of $\mathrm{Co}$ (II), $\mathrm{Ni}(\mathrm{II}), \mathrm{Cu}(\mathrm{II}), \mathrm{Mn}(\mathrm{II})$ and $\mathrm{Fe}$ (III) Complexes. Int. J. Electrochem. Sci., 4, 717-729.

10. Medici, S., Peana, M., Nurchi, V.M., Lachowicz, J.I., Crisponi, G. \& Zoroddu, M.A. (2015). Noble metals in medicine: Latest advances. Coord. Chem. Rev., 284, 329-350.

11. Scheffler, H., You, Y. \& Ott, I. (2010). Comparative studies on the cytotoxicity, cellular and nuclear uptake of a series of chloro gold(I) phosphine complexes. Polyhedron, 29, 66-69.

12. Yeo, C.I., Ooi, K.K. \& Tiekink, E.R.T. (2018). GoldBased Medicine: A Paradigm Shift in Anti-Cancer Therapy? Molecules, 23, 1410; DOI: 10.3390/molecules23061410.

13. Jumaa, T., Chasib, M., Hamid, M.K. \& Al-Haddad, R. (2014). Effect of the Electric Field on the Antibacterial Activity of $\mathrm{Au}$ Nanoparticles on Some Gram-positive and Gram-negative Bacteria. Nanosci. Nanotech. Res., 2(1),1-7; DOI: 10.12691 /nnr-2-1-1.

14. Amin, R.R. (2010). Chemical and Electrochemical Preparation for $\mathrm{Co}(\mathrm{II})$ Complexes of Some Novel Pyridine-2-(1H)- 
-Thione Ring Fused Cycloalkane Derivatives; Phosphorus, Sulfur, and Silicon and the Related Elements 185(3), 537-543.

15. Amin, R.R. \& Elgemeie, G.E.H. (2001). The direct electrochemical synthesis of $\mathrm{Co}(\mathrm{II}), \mathrm{Ni}(\mathrm{II}), \mathrm{AND} \mathrm{Cu}(\mathrm{II})$ complexes of some pyridinethione derivatives; Synth. React. Inorg. Met.-Org. Chem., 31(3), 431-440.

16. Reiss, A., Florea, S. \& Rudorf, W.D. (2000). Transition metal complexes of heterocyclic ligands. Part III. Complexes of 6-aryl-3- cyano-4-trifluormethyl-pyridine-2(1H)-thione with $\mathrm{Co}(\mathrm{II}), \mathrm{Ni}(\mathrm{II}), \mathrm{Cu}(\mathrm{II})$ and $\mathrm{Zn}(\mathrm{II})$. Polish J. Chem. 74, 589-594.

17. Rodinovskaya, L.A, Sharanin, Yu.A., Litvinov, V.P., Shestopalov, A.M., Promonenkov, V.K., Zolotarev, V.K., Mortikov, V.Yu., (1985). Nitrile cyclization reactions. 8. Synthesis and transformation of 6-aryl-4-trifluoromethyl-3-cyano-2 (1H)pyridinethiones. Zh. Org. Khim., 212439.

18. Reeves, D.S. \& White, L.O. (1983) Principles of methods of Assaying Antibiotics in Pharmaceutical Microbiology, 3rd ed., Blackwell Scientific Publication, p. 140-162.

19. Winter, C.A., Risley, E.A., Nuss, G.W. (1962). Carrageenin-Induced Edema in Hind Paw of the Rat as an Assay for Antiinflammatory Drugs. Proc. Soc. Exp. Biol. Med. 111, 544-547. https://doi.org/10.3181/00379727-111-27849. 